УДК 162.6

В. Л. Бабюк, аспірантка

\title{
КРИТЕРІЇ ОЦІНКИ АРГУМЕНТАЦІї: НЕФОРМАЛЬНА ЛОГІКА VERSUS ФОРМАЛЬНА ДІАЛЕКТИКА
}

Актуальність теми дослідження. Дослідження оцінки аргументації є важливим для сучасної теорії аргументації з огляду на відсутність універсального підходу до розуміння критеріїв, які можуть слугувати орієнтиром оцінки.

Постановка проблеми. Необхідно з'ясувати, які з запропонованих різними підходами критеріїв оцінки є більш універсальними та враховують специфіку фрункціонування аргументативних міркувань у реальному дискурсі.

Аналіз останніх досліджень і публікацій. Над проблемою критеріїв оцінки аргументації працюють представники неформальної логіки, формальної діалектики, прагма-діалектики та риторичного підходу. Зокрема, Д. Аллен, Е. Блейр, П. Бонді, Д. Волтон, Ч. Ґемблін, Т. Гов'є, Р. Джонсон, К. Тіндейл, Д. Хічкок, Дж. Фрімен, Р. Пінто та ін.

Виділення недосліджених частин загальної проблеми. Ключова роль неформальної моделі оцінки аргументації на сьогодні є загальновизнаною. Але причини, які зумовили такий їі статус залишилися поза увагою науковців.

Постановка завдання. Дослідження має на меті з'ясувати, чому саме нефоормальна модель оцінки стала класичною для теорії аргументації.

Виклад основного матеріалу. У статті здійснено компаративний аналіз досліджуваних моделей оцінки аргументації. З'ясовано, що розуміння суті аргументації є для них спільним. Виявлено, що критерії релевантності та прийнятності у різних формулюваннях представлені в обидвох моделях оцінки. Тоді як критерій достатності недостатньо експлікований у діалектичній моделі.

Висновки. Критерії Ч. Гембліна поступаються неформальним у прагматичному аспекті: зручність, універсальність та чіткість. Це поряд з історичним контекстом могло стати причиною того, що саме нефрормальні критерії стали ключовими для теорії аргументації.

Ключові слова: теорія аргументації; оцінка аргументації; неформальна логіка; формальна діалектика; RAS-модель.

V. L. Babyuk, Postgraduate Student

\section{CRITERIA OF ARGUMENT EVALUATION: INFORMAL LOGIC VERSUS FORMAL DIALECTICS}

Urgency of the research. Investigation of argument evaluation is important for the contemporary argumentation theory because of the lack of a universal approach to understanding the criteria, which can be a guide for such evaluation.

Target setting. It is necessary to find out which of the argument evaluation criteria proposed in different approaches are more universal and take into account the peculiarities of argumentative reasoning operating in real discourse.

Actual scientific researches and issues analysis. Representatives of informal logic, formal dialectics, pragma-dialectics and rhetorical approach work on the problem of argument evaluation criteria. In particular, D. Allen, E. Blair, P. Bondy, J. Freeman, T. Govier, Ch. Hamblin, D. Hitchcock, R. Johnson, R. Pinto, C. Tindale, D. Walton.

Uninvestigated parts of general matters defining. The key role of informal model of argument evaluation is indisputable today. But the reasons which have led to this status were left out of the scientists 'attention.

The research objective. The purpose of the article is to found out why the informal model of evaluation has become classical for the argumentation theory.

The statement of basic materials. It is carried out a comparative analysis of argument evaluation models under consideration. It is revealed that understanding of the argumentation is common to 
them. It has been found that the relevance and acceptability criteria are presented in both evaluation models but in different formulations. At the same time, the sufficiency criterion is not explicated enough in the dialectical model.

Conclusions. Ch. Hamblin's criteria are inferior to the informal in the pragmatic aspect: convenience, versatility and clarity. This and the historical context could have been the reason of becoming informal criteria key to the theory of argument.

Keywords: argumentation theory; argument evaluation; informal logic; formal dialectics; RAS-model.

$$
\text { DOI: 10.25140/2412-1185-2018-2(12)-7-13 }
$$

Актуальність теми дослідження. Теорія аргументації, як дисципліна нормативна, надає чіткі та універсальні норми, стандарти для здійснення аргументації, якими є, зокрема, критерії її оцінки. Оцінка аргументації $є$ однією з найбільш обговорюваних на сьогодні тем у науковій спільноті. Така увага виправдана як теоретичною, так і практичною цінністю досліджень з цієї проблематики.

По-перше, встановлення загальних критеріїв оцінки аргументації дозволить вийти на принципово новий рівень теоретизування, уніфрікувати розмаїття концепцій щодо розуміння кожного 3 критеріїв та щодо того, які саме вимоги до аргументації можуть грати роль цих критеріїв.

По-друге, уміння професійно оцінити аргументацію співрозмовника дозволяє не лише уникнути непорозуміння та введення в оману, а й виводить комунікацію на високий рівень раціональності, де обґрунтованість, послідовність та відповідність нормативним вимогам ведення суперечки замінюють непрофесійне, а тому заплутане і неефективне вирішення конфліктів точок зору.

Постановка проблеми. Історична перспектива дослідження оцінки аргументації відсилає до працюючої логіки Стівена Тулміна, який, однак, не робить спроби створити систему критеріїв для виявлення «сильної» аргументації, обґрунтовуючи їх залежність від сфрери, де здійснюється аргументація[7].

Отож, система критеріїв оцінки аргументації розробляється пізніше: у 1970 році Чарльз Леонард Ґемблін видає працю «Помилки», у якій, зокрема, виводить низку критеріїв для оцінки аргументативних міркувань. На сьогодні класичною системою оцінки вважається модель, сформульована у 1977 році Е. Блейром та Р. Джонсоном у праці «Логічний самозахист».

Аналіз останніх досліджень і публікацій. Дослідження оцінки аргументації як в загальному, так і щодо конкретних критеріїв, представлені в основному Північноамериканською та Амстердамською школами. При цьому, специфріка сучасної теоретико-аргументативної спільноти полягає у тісній співпраці дослідників різних течій та напрямків: неформальної логіки, формальної діалектики, риторичного підходу, прагма-діалектики.

Ключовими для оцінки аргументації є праці таких дослідників, як Д. Аллен [D. Allen], E. Блейр [J. A. Blair], П. Бонді [P.Bondy], Д. Волтон [D.Walton], Ч. Ґемблін [Ch. Hamblin], Т. Г ов'є [T. Govier], P. Джонсон [R. H. Johnson], К. Тіндейл [Chr. W. Tindale], Д. Хічкок [D. Hitchcock], Дж. Фрімен [J. Freeman], P. Пінто [R. Pinto] тощо.

Виділення недосліджених раніше частин загальної проблеми. Незважаючи на активні дискусії у наукових колах з приводу оцінки аргументації, залишається недослідженим її історичний зріз, аналіз якого необхідний для розуміння механізму відбору критеріїв для оцінки аргументації, а також суті кожного з критеріїв, що стали загальноприйнятими.

Постановка завдання. Одним із завдань цієї статті $є$ виявлення причин, які зумовили те, що саме ця модель оцінки стала класичною для теорії аргументації. Окрім цього, ми з'ясуємо, які відмінності наявні між системою критеріїв Ч. Ґембліна та Е. Блейра і Р. Джонсона, а також визначимо сильні та слабкі сторони цих моделей оцінки.

Виклад основного матеріалу.

Аргументація як предмет оцінки. Для аналізу критеріїв оцінки аргументації у означених підходах необхідно з'ясувати, чи збігається їх розуміння предмету оцінки - аргументації - в цілому.

Обидві концепції розглядають аргументативні міркування, систему критеріїв для яких необхідно вибудувати, як такі, що функціонують у реальному комунікативному дискурсі. Зокрема, акцентується увага на практичній складовій: «Якщо $\mathrm{P}$, то Q» взагалі не $є$ реальною аргументаці-

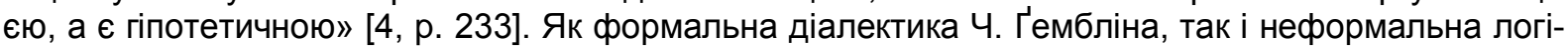


ка Р.Джонсона і Е. Блейра вказують на переконуваність як ключову рису успішної аргументації. Визнають недостатність та необов'язковість валідності: «Мабуть, якщо хороша аргументація має істинні засновки та задовільний процес висновування, то вона також повинна мати істинний висновок? На жаль, справа не настільки проста» [4, р. 232]. У зв'язку з цим обидві концепції відмовляються від поняття валідності у аспекті аргументативних міркувань, замінивши його на «хороша» (good) аргументація» [4, р. 230; 5].

Ч. Ґемблін проводить чітку демаркацію між теоретичною логікою та логікою практики, яка і $\epsilon$ сорерою аргументації: «...ми повинні перейти на один крок ближче до реальності. Коли ми надаємо приклад аргументації, ми повинні уявити собі, як хтось фактично сперечається, а не уявлення чийогось уявлення про суперечку» [4, р. 233].

У «Логічному самозахисті» Е. Блейр та Р. Джонсон звертаються до поняття реальної аргументації, яке за змістом збігається з Ґемблінівським розумінням предмету дослідження. Реальна аргументація - та, яка використовується у повсякденному дискурсі, під яким розуміється як буденне спілкування, так і у сфрері політики, ЗМІ, реклами. Реальна аргументація протиставляється, з одного боку, штучній формалізованій, з іншого - спеціальній науковій аргументації [5].

Для оцінки реальної аргументації критерій істинності засновків та логічної правильності висновування видаються неефективними.

Класичною для сучасної теорії аргументації є так звана RAS-модель оцінки, до якої входять такі критерії, як релевантність (relevance), прийнятність (acceptability) та достатність (sufficiency). Вона робить можливим врахування у побудові аргументації саме тих якостей, відсутність яких призводить до найбільш поширених логічних помилок. Автори «Логічного самозахисту» виводять ці критерії побіжно, для подальшого аналізу конкретних помилок. Але саме ця модель зайняла центральне місце у оцінці аргументації і залишається актуальною й зараз для фрактично всіх сучасних шкіл теорії аргументації [5].

Діалектичні критерії оцінки аргументації. На час видання «Логічного самозахисту» уже сім років існує праця австралійського логіка Ч. Ґембліна «Помилки», у якій детально прописуються критерії оцінки хорошої аргументації. Вона вважається класичною для сучасної теорії аргументації, незважаючи на те, що розвиток цієї дисципліни з кінця 1970-х сконцентрувався у Канаді та Нідерландах. Основна увага послідовників надається класифікації помилок в аргументації, в той час, як вперше сфрормульовані критерії її оцінки залишилися обабіч наукових досліджень. У 1977 році у праці «Логічний самозахист» Ральф Джонсон та Ентоні Блейр виводять власні критерії, які й увійшли в науковий обіг та є актуальними до сьогодні.

Ч. Ґемблін виводить декілька типів критеріїв: алетичні, епістемічні та діалектичні. Судячи 3 особливостей кожного з цих типів, можна зробити висновок, що вони можуть використовуватися для різних цілей: коли алетичних достатньо для з'ясування логічної правильності, то діалектичні враховують комунікативну складову, не відривають аргументацію від дискурсу, тим самим залишаючи її такою, як вона дійсно відбувається [4].

Окрім цього варто звернути увагу на співвідношення типів критеріїв: епістемічні дозволяють перейти від теоретичності та відірваності від реальної комунікації алетичних критеріїв. Однак, вони оперують поняттям знання, а тому є сильнішими, аніж алетичні. Ґемблін вважає необхідним послабити їх шляхом введення третього рівня критеріїв: діалектичного.

Отож, до алетичних критеріїв належать:

1. істинність засновків;

2. виведення висновку з цих засновків;

3. безпосередність та раціональність процесу висновування;

4. пропущені в аргументації засновки мають бути такими, якими можна знехтувати (omissible) [4, p. 234-235].

Такі критерії задовольняють формальну логіку, але є недостатніми для аналізу аргументації, яку здійснюють люди у реальному житті. Зокрема, вимога істинності не враховує необхідність засновка бути відомим аудиторії як істинний. Хорошою аргументацією, згідно з алетичними критеріями, буде та, яка має істинні засновки і безпосередньо виведений з них висновок. Ці критерії не враховують випадки, коли невідомо, чи дійсно засновки істинні. Ґемблін наводить приклад аргументації «марсіанські канали не є штучними, оскільки на Марсі ніколи не було органічного життя»[4, р. 236]. Ї̈̈ засновок відомий як істинний, і тому, по-перше, аргументація не має сенсу, якщо ії̈ адресатами будуть, наприклад, середньовічні монахи, яким нічого не відомо про Марс; 
по-друге, сенс словосполучення «відомий як істинний» передбачає можливість гіпотези у засновку, яка не є фактом. Отже, для Ґембліна відірваність поняття істинності, ключового для алетичних критеріїв, від практичного аргументативного процесу стає причиною їх заміни епістемічними: «важливо перейти до додаткових або модифікованих критеріїв оцінки, які мають відношення до того, коли логіка стає працювати»[4, р. 236].

До епістемічних критеріїв відносяться:

1. Засновки мають бути відомі як істинні;

2. висновок має випливати з засновків;

3. процес висновування має бути ясним;

4. пропущені засновки мають бути зрозумілі самі собою та бути істинними;

5. за відсутності аргументації висновок має бути сумнівним [4, р. 236-238].

Такий набір критеріїв, як бачимо, розширений порівняно з алетичними, в тому числі, за рахунок додавання останнього правила, яке стосується практичного аспекту аргументування. А саме, якщо висновок відомий у такій самій мірі, як засновки, аргументація не матиме практичного сенсу. Як зазначає Ч. Ґемблін, «на практиці ніхто не зацікавлений в правдоподібній аргументації, якщо правдоподібність засновків не перевищує а рriорі неправдоподібності висновку»[4, р. 239].

Все ж, епістемічні критерії, на думку Ч. Ґембліна, необхідно послабити у аспекті поняття знання. Адже у практичному дискурсі ми зазвичай маємо справу з переконаннями, припущеннями учасників аргументації, які не є знанням у строгому епістемічному сенсі. Так логік підходить до наступного рівня критеріїв: діалектичного. Ключовим концептом на цьому рівні розгляду аргументації є прийнятність, яка фактично займає місце істинності у алетичних та епістемічних критеріях.

Введення поняття прийнятності принципово трансформує погляд оцінювача, який є спостерігачем, на аргументативний процес. Адже «коли дехто каже "P тому Q", це означає “Я наводжу P на підтримку $Q$ ” і неважливо, чи $є P$ або $Q$ істинними об'єктивно. Важливо те, що мовець та сприймач приймають $\mathrm{P}$ та $\mathrm{Q}$ як істинні» [4, p. 245].

Отож, система діалектичних критеріїв Ч. Ґембліна виглядає так:

1. Засновки мають бути прийнятими у сенсі «Прийняті х»;

2. перехід від засновків до висновка має бути прийнятним;

3. прийнятий перехід має бути раціонально неопосередкованим;

4. невстановлені засновки мають бути прийнятими як такі, якими можна знехтувати;

5. висновок має бути таким, що не є прийнятим за відсутності аргументації [4, р. 244].

Одразу варто звернути увагу на смислову відмінність термінів «прийнятний» (acceptable) та «прийнятий» (accepted). Прийнятність означає апріорну властивість бути прийнятим, або ж потенційну можливість таким стати. Тоді як «бути прийнятим» означає фракт, безпосередню даність у конкретному контексті. Ч. Ґемблін вживає слово «прийнятий», таким чином концентруючись на конкретній аргументації. У подальшому розвитку теорії аргументації, зокрема у «Логічному самозахисті» слово «прийнятний» має те ж значення, що й Ґемблінове «прийнятий». Відмінність полягає у аспекті вживання: прийнятний як універсальний критерій, прийнятий кимось у реальному аргументативному процесі.

3 іншого боку, необхідно розуміти, що прийнятність сама по собі - фрікція, адже засновок може бути прийнятним лише для суб'єкта. Бути прийнятним у аргументативному контексті означає бути прийнятним для того, кому аргументація адресується. Отож, принципова орієнтованість на аудиторію - будучи базовою рисою аргументативного дискурсу - визначає і аспект істинності у ньому, котрий трансформується не просто в «істинне для когось», а в «прийнятне для когось» або ж «прийняте кимось».

Отож, діалектичні критерії оцінки аргументації є більш близькими до реального процесу аргументування, ніж алетичні та більш слабкими, аніж епістемічні.

При цьому, Ч. Ґемблін справедливо зауважує про опосередкованість місця логіка, або ж теоретика аргументації, який здійснює оцінку. Оцінювач особисто не залучений в аргументацію. Він лише здогадується (припускає), що саме з засновків є прийнятним для ії учасників. Саме тому для нього стають важливими поняття істинності та правильності (в сенсі valid), які є єдиним, що доступне спостерігачу[4, р. 246].

Неформальні критерії оцінки аргументації. У 1977 році виходить друком праця Р. Джонсона та Е.Блейра «Логічний самозахист», яка дала початок напрямку, що отримав назву нефор- 
мальної логіки. У цій праці вперше після Ч. Ґембліна висунуто ряд критеріїв оцінки аргументації, яка зустрічається у реальному житті: повсякденному, політичному, суспільному дискурсі. Хоч автори не могли на той час не бути знайомими з «Помилками», вони висувають власну класифікацію помилок та відповідних критеріїв оцінки, відповідність яким дозволяє цих помилок уникнути. До цих критеріїв належать:

1. прийнятність засновків;

2. релевантність засновків до висновку;

3. достатність засновків[5].

Різноманіття аргументативних помилок не вичерпується трьома, але ці критерії містять у собі базові загальні вимоги, порушення яких у той чи інший спосіб призводить до відповідної помилки.

Прийнятність, яка у неформальній логіці заміняє собою формальний критерій істинності, постулює вимогу до засновків бути прийнятними для учасників аргументації, що є умовою для того, щоб аргументація могла вважатися хорошою. Поштовхом до заміни критерію істинності критерієм прийнятності став аналіз аргументацій, наприклад, етичного спрямування, які часто містять засновки, яким не можна надати значення істинності чи хибності[1, р. 2]. Одразу звернемо увагу, що Ч. Ґемблін починає розвідки з діалектичних критеріїв також під впливом міркувань, засновки яких не можна кваліфікувати як істинні чи хибні.

Як зазначає Т. Гов'є, «прийнятність не є прийнятістю» [3, р. 284]. Це означає, що прийнятність - поняття нормативне, засновок є прийнятним тільки тоді, коли раціонально прийняти його [6, р. 122]. Це не те ж саме, що істинність: твердження, переконаність у яких є раціональною, є прийнятними в якості засновків, навіть якщо вони можуть виявитися хибними. Прийнятність пов'язана зі знаннями суб'єкта, і тому може варіюватися залежно від того, хто сприймає аргументацію. Так, певний засновок може бути прийнятним для Сміта, адже його попереднє знання дозволяє йому раціонально судити про засновок як такий, який варто прийняти. Той самий засновок може бути неприйнятним для Джонса, первинне знання якого відмінне від Смітового, і для нього раціонально не прийняти засновок [6, р. 123].

Прийнятність може змінюватися з часом. Так, твердження, прийнятне для декого зараз може бути неприйнятним для нього через рік, адже він може отримати додаткову інформацію, яка посіє сумнів у цьому засновку [6, р. 123].

Прийнятність $€$ властивістю, що належить кожному засновку, взятому самому по собі. Тому важливо оцінювати прийнятність кожного засновка окремо [6, р. 123].

На сьогодні немає однозначного погляду на місце критерію прийнятності у оцінці аргументації. Показовими видаються позиції, з одного боку, Д. Аллена, який вказує на релятивізм такого розуміння у зв'язку з тим, що пропозиція р не просто прийнятна, а прийнятна для однієї або декількох осіб у певний час [1]. 3 іншого боку, Т. Гов'є яка вважає, що для оцінки реальної аргументації критерій прийнятності більш практичний, адже, «прийнятність засновків $є$ вирішальною у випадках, коли вони не мають значення істинності». [3, р. 280]

Незважаючи на поліфонію в сучасній теорії аргументації у аспекті критерію прийнятності, залишається фактом його широкий вжиток. В цей час, критика його є досить м'якою. Зокрема, Д. Аллен зауважує про доречність використання одночасно двох критеріїв щодо засновків: істинності та прийнятності, з яких перший робитиме аргументацію хорошою у логічному сенсі, другий - у гносеологічному [1, р. 9].

Схожої думки дотримується Е. Блейр, який зазначає, що протиріччя між істинністю та прийнятністю можна вирішити розмежуванням типів діалогу, у яких здійснюється оцінювана аргументація. Це, з одного боку, діалог-переконання, учасники якого використовують засновок з метою зміни точки зору. 3 іншого боку, діалог-обґрунтування, у якому виправдовується уже наявне переконання (рішення, вибір, відношення). У випадку діалогу-переконання норми прийнятності встановлюються учасниками, тоді як в обґрунтуванні завдання аргументації - не встановити, що слідує з зобов'язань аудиторії, а що слідує з того, що прийняття засновку аудиторією $є$ виправданим (обґрунтованим) [2, р. 94]

Р. Джонсон вважає, що теоретики, які повністю відмовляються від критерію істинності (Ч. Ґемблін, наприклад), насправді його використовують, не артикулюючи. Наприклад, для перевірки аргументації на релевантність: «А є правдоподібно релевантним $B$, тільки якщо істинність $А$ відмінна від істинності В». Джонсон називає це вимогою істинності. Ґемблін ставить прийнятність 
замість істинності, і така позиція знаходить відгук у прагма-діалектиці: якщо аргументатор і реципієнт приймають засновок, він вважається прийнятним для аргументації [2].

Критерій релевантності у загальному можна сформулювати так: релевантний засновок - такий, що відповідає темі висновку. Подальші дослідження цього критерію у неформальній логіці призвели до його диференціації, яка унеможливлює надання єдиного визначення, адже воно завжди буде занадто загальним.

Релевантність у сучасних дослідженнях Е. Блейра та Д. Волтона означає здатність обмежувати аргументацію в тематичному аспекті, що проявляється у викресленні з аргументації всіх недоречних, невідповідних тезі, засновків. Релевантність здійснює функцію контролю на вході того, що призводить до її неефективності на виході. Д. Волтон називає це функцією виключення (exclusionary) [8, p. 2].

Для Е. Блейра релевантність виступає своєрідним критерієм відповідності, включення в аналіз і реконструкцію аргументації з дискурсу. Так, лише доказово релевантні пропозиції мають бути включені в аналіз як засновки. Цей критерій грає роль в оцінці аргументації лише тоді, коли дискурс і контекст дають зрозуміти, що автор мав намір зробити твердження засновком чи тезою, навіть якщо таке твердження не має доказової сили щодо тези [2, р. 92].

Критерій достатності у «Логічному самозахисті» та подальших дослідженнях з теорії аргументації використовується для оцінки того, чи достатньо усіх наведених засновків для підтримки тези, що захищається.

Точки перетину в неформальній та діалектичній моделях оцінки аргументації. Спільним для формальної діалектики та неформальної логіки є критерій прийнятності. Початкове його розуміння сутнісно збігається. Відмінність полягає у тому, що подальший розвиток неформальної логіки спричинив глибший і більш сутнісний аналіз цього критерію, що призвело до його критики та, відповідно, трансформації у вигляді послаблення диз'юнкції між критерієм істинності та прийнятності. Остаточного задовільного для більшості теоретиків аргументації розуміння цього критерію немає й на сьогодні.

Концепт доказової релевантності, яка надає підтримку висновку безпосередньо, негайно (на відміну від глобальної релевантності, яка передбачає врахування в якості релевантних засновків додаткових припущень, які не впливають на висновок безпосередньо) також по суті збігається з діалектичними критеріями: «перехід від засновків до висновку має бути прийнятого типу» та «перехід має бути раціонально неопосередкованим». Саме релевантність забезпечує перехід від засновків до висновку, уможливлює причинно-наслідковий зв'язок між ними.

На наш погляд, також очевидною здається аналогія Ґемблінового правила «Невстановлені засновки мають бути прийняті як такі, якими можна знехтувати» та критерію достатності. Щоправда, тут дається взнаки або нечіткість Ґемблінового формулювання, або ж неврахування позитивного сенсу достатності: всі встановлені засновки мають бути такими, якими знехтувати не можна; та похідного, який можна вивести: встановлених засновків має бути достатньо для обґрунтування висновку. Власне, це похідне неекспліковане правило співзвучне з неформальним критерієм достатності.

Залишається без відповідника у неформальній логіці вимога Ч. Ґембліна до висновку бути менш прийнятним за відсутності аргументації, аніж за її наявності. При цьому, в усіх сучасних школах теорії аргументації визнається, що аргументація має сенс лише тоді, коли дійсно щось обґрунтовує або у чомусь переконує. Е. Блейр та Р. Джонсон не відносять цю вимогу до критеріїв оцінки. На наш погляд, це додаткове правило, яке Ч. Ґемблін встановлює серед діалектичних вимог до аргументації, можна порівняти з іншими вимогами, які, однак, не є критеріями (наприклад, наявність спільного контексту).

Висновки. Підсумовуючи, варто відповісти на питання про поширення у логічній спільноті критеріїв Е. Блейра та Р.Джонсона. На нашу думку, ситуативною причиною є, насамперед, велика увага до цієї проблематики всередині неформальної логіки, поштовх для розвитку якої дала саме праця «Логічний самозахист». Прагматична складова стосується практичної зручності в оцінці аргументації за чіткими універсальними неформальними критеріями, тоді як про певну неуніверсальність та заплутаність діалектичних вказує і сам автор.

Варто наголосити, що можна знайти прямі аналогії між критеріями оцінки Ч. Ґембліна та Е. Блейра й Р. Джонсона. По-перше, фрактично немає відмінностей у розумінні порівнюваними системами оцінки критерію прийнятності. У статті подано сучасний погляд на проблематичність 
деяких критеріїв, але у контексті порівняння критеріїв «Логічного самозахисту» та «Помилок», беремо до уваги лише первинне їх розуміння.

По-друге, можна провести аналогію між критерієм релевантності та діалектичними критеріями «перехід від засновків до висновку має бути прийнятого типу» та «перехід має бути раціонально неопосередкованим».

По-третє, критерій достатності тематично відповідає діалектичному «Невстановлені засновки мають бути прийняті як такі, якими можна знехтувати». Щоправда, його формулювання є неточним і поступається неформальному строгістю, силою та чіткістю.

Додаткова діалектична вимога більшої обґрунтованості висновку за наявності аргументації, аніж без неї, не має аналогу в RAS-моделі. Нам вона видається радше загальновизнаним правилом, порушення якого суперечитиме раціональності учасників аргументації. Все ж, вона може виступати критерієм оцінки, адже хороша аргументація - як переконання, так і обґрунтування дійсно повинна збільшувати правдоподібність висновку.

Питання про те, чи варто робити цю вимогу до аргументації критерієм її оцінки залишається відкритим для подальших наукових пошуків.

\footnotetext{
Література

1. Allen, D., "Should We Assess the Basic Premises of an Argument for Truth or Acceptability?", OSSA Conference Archive, Paper 6, May 15, 1997.

2. Blair, J. A., The Groundwork of Argumentation Theory, Springer, 2012.

3. Govier, T., Problems in Argument Analysis and Evaluation, Dordrecht-Holland: Foris Publications, 1987.

4. Hamblin, Ch. L., Fallacies, Methuen young books; 1st edition, 1970.

5. Johnson, R. H., Blair J. A., 1994, Logical self-defence, McGraw-Hill, Inc., US edition.

6. Pinto, R. C., J. A. Blair, K. E. Parr. Reasoning. Scarborough: Prentice-HallCanada Inc., 1993.

7. Toulmin S., The uses of argument, Cambridge University Press; Updated edition, 2003.

8. Walton, D., Relevance in argumentation, Amsterdam, Routledge, 2003.
}

\section{References}

1. Allen, D. (1997). Should We Assess the Basic Premises of an Argument for Truth or Acceptability? OSSA Conference Archive, 6 [in English].

2. Blair, J. A. (2012). The Groundwork of Argumentation Theory, Springer [in English].

3. Govier, T. (1987). Problems in Argument Analysis and Evaluation, Dordrecht-Holland: Foris Publications [in English].

4. Hamblin, Ch. L. (1970). Fallacies. Methuen young books; 1st edition [in English].

5. Johnson, R. H., Blair, J. A. (1994). Logical self-defence. McGraw-Hill, Inc., US edition [in English].

6. Pinto, R. C., J. A. Blair, K. E. Parr (1993). Reasoning. Scarborough: Prentice-HallCanada Inc. [in English]

7. Toulmin, S. (2003). The uses of argument. Cambridge University Press; Updated edition [in English].

8. Walton, D. (2003). Relevance in argumentation. Amsterdam, Routledge [in English].

Бібліографічний опис для цитування :

Бабюк, В. Л. Критерії оцінки аргументації: неформальна логіка versus формальна діалектика / В. Л. Бабюк // Проблеми соціальної роботи: фрілософрія, психологія, соціологія. - 2018. - № 2 (12). - С. 7-13. 